\title{
Lattice radiation therapy - its concept and impact in the immunomodulation cancer treatment era
}

Antonio Cassio Assis Pellizzon ${ }^{\mathbf{1}}$

1. A.C.Camargo Cancer Center, Departamento de Radio-Oncologia, São Paulo, SP, Brasil.

http://dx.doi.org/10.1590/1806-9282.66.6.728

\begin{abstract}
SUMMARY
Voluminous tumors represent a challenge in radiation oncology, particularly when surgical resection is not possible. Lattice radiotherapy (LTR) is a technique that may provide equivalent or superior clinical response in the management of large tumors while limiting toxicity to adjacent normal tissues. LRT can precisely deliver inhomogeneous high doses of radiation to different areas within the gross tumor volumes (GTV). The dosimetric characteristic of LTR is defined by the ratio of the valley dose (lower doses - cold spots) and the peak doses, also called vertex (higher doses - hot spots), or the valley-to-peak dose ratio. The valley-to-peak ratio thereby quantifies the degree of spatial fractionation. LRT delivers high doses of radiation without exceeding the tolerance of adjacent critical structures. Radiobiological experiments support the role of radiation-induced bystander effects, vascular alterations, and immunologic interactions in areas subject to low dose radiation. The technological advancements continue to expand in Radiation Oncology, bringing new safety opportunities of treatment for bulky lesions.
\end{abstract}

KEYWORDS: Radiotherapy. Immunology. Dose fractionation, radiation. Immunomodulation. Neoplasms.

\section{INTRODUCTION}

Voluminous tumors represent a challenge in radiation oncology, particularly when surgical resection is not possible. In many situations, conventional-dose radiation with or without chemotherapy has limited efficacy for local control. Lattice radiotherapy (LTR) is a technique based on 3-dimensional plans derived from grid radiation therapy. Grid was used to deliver tumoricidal doses of radiation to deep-seated tumors in the orthovoltage era, due to skin toxicity and difficulties in dose distribution' ${ }^{1}$. Lattice may provide equivalent or superior clinical response in the management of large tumors while limiting toxicity to adjacent normal tissues. LRT can precisely deliver inhomogeneous high doses of radiation to different areas within the gross tumor volumes (GTV). Recently, tridimensional plans (3D) started to be used for LTR planning and delivery ${ }^{2}$.

\section{LTR DOSIMETRIC CHARACTERISTICS}

The principle of LTR is based on the use of volumes of high-dose areas, called vertices, distributed within the central areas of the GTV and lower dose areas, also within the GTV, called valleys. This high-dose of radiation is delivered to the bulk of the tumor, sparing the peripheral areas and normal tissues ${ }^{3}$.

The dosimetric characteristic of LTR is defined by the ratio of the valley dose (lower doses - cold spots) and the peak doses, also called vertex (higher doses - hot spots), or the valley-to-peak dose ratio. The valley-to-peak ratio thereby quantifies the degree of spatial fractionation².

Developments in 3-dimensional planning are important in LTR. For LTR planning, important parameters include the vertex volume diameter and 
center-to-center spacing. By Monte Carlo simulations, Gholami et al. ${ }^{4}$ found that hot spots diameters of 1 to $1.25 \mathrm{~cm}$ and separated by 1.7 to $1.8 \mathrm{~cm}$ are key to optimize therapeutic ratio and normal tissue sparing.

\section{RADIOBIOLOGICAL MECHANISMS}

The main radiobiological mechanisms related to LTR involve radiation-induced bystander effects, microvascular alterations, and immunomodulation ${ }^{2}$.

A classification of more general radiation-induced signaling effects based on human radiation exposure scenarios divided the effects into three categories: bystander, cohort, and abscopal effects. The bystander effects are defined for human exposure scenarios as radiation-induced, signal mediated effects in unirradiated cells adjacent to a target volume that are exposed to only very low levels of scatter radiation. The second classification of effects, termed cohort effects, describes the overall radiobiological response in irradiated cells that is not a consequence of direct energy deposition in the target cell, but due to the communication between cells within an irradiated volume. Cohort effects are relevant for any exposures in which most of a cell population is exposed to a significant dose. This effect is based on intercellular signaling ${ }^{5,6}$. The abscopal effect refers to an immune-mediated response of distant lesions to irradiation of other lesions ${ }^{7}$.

Large tumor volumes, in general, have a poor blood supply that leads to hypoxic volumes within the tumor that stimulates the production of factors such as hypoxia-inducible factor 2 alpha (HIF-2 $\alpha$ ) thus reducing apoptosis ${ }^{8}$. High doses of radiation can increase apoptosis due to the bystander effects via secondary cellular signaling either by direct physical contact or by cell-released signaling molecules - cytokines, nitric oxide, or reactive oxygen species. For LTR, most of the benefits would come from the destruction of volumes of the tumor receiving the highest dose of radiation while inducing bystander effects in those peripheral cells that are well within the target but farther away from healthy adjacent structures ${ }^{9}$.

High doses of radiation have been shown to cause endothelial apoptosis through the production of soluble factors, consequently altering tumor microvasculature, which is vital for tumor growth and metastatic evolution $^{10}$.

\section{IMMUNOMODULATION}

Radiation is known to be a potent immune-modulator that elicits cell death upon the tumor, stromal and angiogenic compartments of the tumor microenvironment. The use of ablative radiation doses can impact local and metastatic or distant tumor control through the modulation of tumor-immune micro-environment and activating the host immune system ${ }^{\mathbf{1 0}}$.

LRT, through its high-dose component, also induces immune responses. It can modify the immunosuppressive tumor environment, potentially enhancing antigen-specific immunotherapy. Radiation kills not only cancer cells, but other cells within the tumor stroma, including endothelial cells and intra-tumoral lymphocytes, leading to an induced upregulation and activation of macrophages genes. The macrophage activation is also induced by signals from apoptotic cells. Furthermore, this stimulation of the host immune response could be responsible for the abscopal effect ${ }^{11}$. Other possible mechanisms of synergic effects of irradiation combined with immunotherapy include enhancement of T cell infiltration and inhibition of myeloid-derived suppressor cells (MDSCs) and regulatory $\mathrm{T}$ cells ${ }^{12}$. Local irradiation also enhances effector T lymphocytes, E7-specific antibodies, and decreases regulatory $\mathrm{T}$ cells ${ }^{\mathbf{1 3}}$.

It is important to note that greater irradiation doses above the threshold of ablative doses do not enhance the potency of antigen-specific immunotherapy $^{\mathbf{1 4}}$. Chang et al. ${ }^{13}$, in an experiment, observed that a biweekly moderate radiation regimen (6 Gy twice a week) combined with the DNA vaccine generated more potent antigen-specific immunologic responses and anti-tumor effects when compared with groups treated with local irradiation or immunotherapy alone, or other radiation fractions (3 Gy four times per week or 12 Gy once per week).

The lymphocytes are considered very vulnerable to radiation, and therefore radiation therapy is taken to be immunosuppressive; however, some studies have already shown an increment in tumor-infiltrating lymphocytes after irradiation. This also stimulates the activity of antigen-presenting cells, which, in turn, primed CD8+ T cells in draining lymph nodes. The number of cytotoxic T cells infiltrating the irradiated tumor increases after radiation therapy, and, in a study by Lugade et al. ${ }^{15}$ it was noted that a single fraction of 15 Gy was more effective in this setting than 15 Gy over 3 fractions. 
Radiation therapy was also shown to upregulate Type 1 interferon, which is necessary for T cell priming by dendritic cells. The presentation of exogenous antigen molecules, known as cross-presentation, is essential for the initiation of CD8(+) T cell responses. In vivo, cross-presentation is mainly carried out by specific dendritic cell subsets through an adaptation of their endocytic and phagocytic pathways ${ }^{16,17}$. Dendritic cells are the main antigen-presenting cells for the induction of T-cell adaptive responses. Cancer cells express tumor antigens, including neo-antigens generated by non-synonymous mutations, but are poor for antigen presentation and for providing co-stimulatory signals for T-cell priming. Evidence suggests that antigen transfer to dendritic cells and their presentation to histocompatibility complex molecules plus co-stimulatory signals is paramount for the induction of cancer immunity ${ }^{18}$.

\section{CURRENT INDICATIONS}

Currently, the use of LTR has been reported for tumors $>45 \mathrm{cc}$, primary or secondary, arising in the lung, pancreas, cervix, rectum, brain, retroperitoneal, and extremity sarcomas, kidney, melanoma, recurrent and metastatic tumors ${ }^{3}$.

Current indications include bulky or locally advanced disease that would not be tractable by conventional radiation or that has been proven to be refractory to chemoradiation. Early-phase clinical trials have shown remarkable success, with some response rates $>60 \%$ and minimal toxicity ${ }^{14}$.

\section{TOXICITY}

One important thing is that applying LRT to large volume tumors would not incur additional toxicity to the surrounding normal tissues since the high-dose volumes are situated within the GTV. The presence of low dose volumes also inside the GTV preserve the vasculature and lymphatic drainage, allowing immunogenic-activated cells to circulate and, subsequently, maximize bystander and abscopal effects ${ }^{10}$.

\section{CONCLUSION}

LRT delivers high doses of radiation without exceeding the tolerance of critical structures. Radiobiological experiments support the role of radiation-induced bystander effects, vascular alterations, and immunologic interactions.

Technological advancements continue to expand in Radiation Oncology and, despite the fact that more clinical and biological data are needed to specify the ideal dosimetric parameters and to formulate robust clinical indications, LTR is an additional treatment option for bulky tumors unsuitable for surgery.

\section{Conflict of interest statement}

I have nothing to disclose.

\section{RESUMO}

Tumores volumosos representam um desafio para a radio-oncologia, em especial quando a ressecção cirúrgica não é possível. A radioterapia com técnica Latisse (LTR) pode gerar resposta clínica equivalente ou superior ao tratamento convencional de grandes tumores, limitando a toxicidade nos tecidos normais adjacentes. A LRT pode fornecer com precisão altas doses não homogêneas de radiação em diferentes áreas do volume tumoral (GTV). A característica dosimétrica da LTR é definida pela razão entre a dose na região do vale (doses mais baixas - pontos frios) e as doses de pico, também chamadas de vértice (doses mais altas - pontos quentes) ou a razão da dose vale/pico. Dessa forma, a razão vale/pico quantifica o grau de fracionamento espacial da entrega de dose. A LRT entrega, dessa forma, altas doses de radiação sem exceder a tolerância de estruturas críticas adjacentes. Experimentos radiobiológicos suportam o chamado "efeito espectador" induzido por radiação, o qual promove alterações vasculares e interações imunológicas, levando à resposta tumoral mesmo em áreas expostas a baixas doses de radiação. Os avanços tecnológicos continuam a se expandir na radio-oncologia, trazendo, por meio da LTR, uma nova oportunidade segura de tratamento para lesões volumosas.

PALAVRAS-CHAVE: Radioterapia. Imunologia. Fracionamento da dose de radiação. Imunomodulação. Neoplasias.

\section{REFERENCES}

1. Marks H. Clinical experience with irradiation through a grid. Radiology. 1952:58(3):338-42.

2. Billena $C$, Khan AJ. A current review of spatial fractionation: back to the future? Int J Radiat Oncol Biol Phys. 2019;104(1):177-87.
3. Blanco Suarez JM, Amendola BE, Perez N, Amendola M, Wu X. The use of lattice radiation therapy (LRT) in the treatment of bulky tumors: a case report of a large metastatic mixed Mullerian ovarian tumor. Cureus. 2015;7(11):e389. 
4. Gholami S, Nedaie HA, Longo F, Ay MR, Dini SA, Meigooni AS. Grid block design based on Monte Carlo simulated dosimetry, the linear quadratic and Hug-Kellerer radiobiological models. J Med Phys. 2017;42(4):213-21.

5. Blyth B|, Sykes P. Radiation-induced bystander effects: what are they, and how relevant are they to human radiation exposures? Radiat Res. 2011;176(2):139-57.

6. Butterworth KT, McMahon SJ, Hounsell AR, O'Sullivan JM, Prise KM Bystander signalling: exploring clinical relevance through new approaches and new models. Clin Oncol (R Coll Radiol). 2013;25(10):586-92.

7. Mole $\mathrm{RH}$. Whole body irradiation; radiobiology or medicine? $\mathrm{Br}$ | Radiol. 1953;26(305):234-41.

8. Asur R, Butterworth KT, Penagaricano JA, Prise KM, Griffin RJ. High dose bystander effects in spatially fractionated radiation therapy. Cancer Lett. 2015;356(1):52-7.

9. Yakovlev VA. Role of nitric oxide in the radiation-induced bystander effect. Redox Biol. 2015;6:396-400.

10. Kanagavelu S, Gupta S, Wu X, Philip S, Wattenberg MM, Hodge JW, et al. In vivo effects of lattice radiation therapy on local and distant lung cancer: potential role of immunomodulation. Radiat Res. 2014;182(2):149-62.

11. Demaria S, Ng B, Devitt ML, Babb JS, Kawashima N, Liebes L, et al. lonizing radiation inhibition of distant untreated tumors (abscopal effect) is immune mediated. Int | Radiat Oncol Biol Phys. 2004;58(3):862-70.
12. Persa $E$, Balogh A, Sáfrány G, Lumniczky K. The effect of ionizing radiation on regulatory T cells in health and disease. Cancer Lett. 2015;368(2):252-61.

13. Chang MC, Chen YL, Lin HW, Chiang YC, Chang CF, Hsieh SF, et al. Irradiation enhances abscopal anti-tumor effects of antigen-specific immunotherapy through regulating tumor microenvironment. Mol Ther. 2018;26(2):404-19.

14. Sura S, Yorke E, Jackson A, Rosenzweig KE. High-dose radiotherapy for the treatment of inoperable non-small cell lung cancer. Cancer J. 2007;13(4):238-42.

15. Lugade AA, Moran JP, Gerber SA, Rose RC, Frelinger JG, Lord EM. Local radiation therapy of $B 16$ melanoma tumors increases the generation of tumor antigen-specific effector cells that traffic to the tumor. J Immunol. 2005; 174(12):7516-23.

16. Burnette BC, Liang $H$, Lee $Y$, Chlewicki L, Khodarev NN, Weichselbaum RR, et al. The efficacy of radiotherapy relies upon induction of type I interferon-dependent innate and adaptive immunity. Cancer Res. 2011;71(7):2488-96

17. Joffre OP, Segura E, Savina A, Amigorena S. Cross-presentation by dendritic cells. Nat Rev Immunol. 2012;12(8):557-69.

18. Sánchez-Paulete AR, Teijeira A, Cueto FJ, Garasa S, Pérez-Gracia JL, Sánchez-Arráez A, et al. Antigen cross-presentation and T-cell cross-priming in cancer immunology and immunotherapy. Ann Oncol. 2017;28(suppl.12):xii44-xii55. 